\title{
Early Eocene evolution of carbonate depositional environments recorded in the Čikola Canyon (North Dalmatian Foreland Basin, Croatia)
}

\author{
Jelena Španiček ${ }^{1}$, Vlasta Ćosović ${ }^{1}$, Ervin Mrinjek ${ }^{1}$ and Igor Vlahović \\ 1 University of Zagreb, Faculty of Science, Department of Geology, Horvatovac 102a, HR-10000 Zagreb, Croatia; \\ (corresponding author: jelena.spanicek@geol.pmf.hr) \\ 2 University of Zagreb, Faculty of Mining, Geology and Petroleum Engineering, Department of Geology and Geological Engineering, Pierottijeva 6, \\ HR-10000 Zagreb, Croatia
}

doi: $10.4154 / g c .2017 .05$

\section{Article history:}

Manuscript received November 08, 2016 Revised manuscript accepted February 25, 2017 Available online February 28, 2017

Keywords: Larger Benthic Foraminifera, microfacies, palaeoenvironment, Foraminifera limestones, North Dalmatian Foreland Basin, Lower Eocene

\begin{abstract}
The stratigraphic succession in the Čikola Canyon (part of the North Dalmatian Foreland Basin) was studied in detail to describe both the sedimentological characteristics and fossil assemblages of the Lower Eocene deposits during the initial stage of the foreland basin formation. The North Dalmatian Basin now represents a part of the Outer Dinarides, and was developed in front of the evolving Dinaric structures by tectonic deformation and marine transgression of an emerged and denuded Mesozoic Adriatic Carbonate Platform (AdCP). During the initial phase, a distal ramp of a foreland basin was formed, characterised by carbonate sedimentation, lasting until the Middle Eocene.

In a studied section more than $300 \mathrm{~m}$ thick, porcelaneous foraminifera, Alveolina, Orbitolites and complex miliolids (Idalina, Periloculina) prevail, associated with conical agglutinated forms, nummulitids and red algae. These samples belong to the SBZ 11-12 (Ypresian), according to occurrences of Alveolina decastroi, Alveolina cremae, Alveolina multicanalifera and Coskinolina liburnica. Two main lithological units have been described: 1) mudstones to wackestones with sporadic occurrences of ostracods and charophyceae, deposited in restricted lagoonal settings with several episodes of freshwater influences, and 2) foraminiferal packstones to grainstones with complex miliolids, alveolinids, corallinacean algae and nummulitids, deposited within inner and middle ramp settings.

Palaeogene deposition of ramp carbonates in the Outer Dinarides area was mainly controlled by the continuous compressional tectonics, and the deposits today appear in more or less discontinuous outcrops. Palaeogene transgression occurred at different times over various parts of the former carbonate platform area, and subsequent carbonate sedimentation was characterised by deposition in similar environments during different time intervals over spatially restricted carbonate ramps controlled by synsedimentary tectonics.
\end{abstract}

\section{INTRODUCTION}

The aim of this study was primarily to determine the microfacies properties of the Čikola river canyon carbonate deposits rich in Larger Benthic Foraminifera (LBF). These determined foraminiferal assemblages and their ecological requirements combined with the study of other carbonate-producing biota (corals, bryozoans, echinoids, molluscs, coralline red algae), enabled the definition of the palaeoenvironmental settings of the Lower Eocene deposits known as the Foraminiferal limestones.

The studied section is located in the Outer Dinarides, the unit being composed mainly of carbonate rocks, ranging in age from the Upper Carboniferous to the Eocene (VLAHOVIĆ et al., 2005). The studied deposits belong to the more or less continuous Palaeogene belt oriented NW-SE along the NE Adriatic coast (ĆOSOVIĆ et al., 2008a) (Fig. 1), i.e. to the North Dalmatian Foreland Basin (BABIĆ \& ZUPANIČ, 1983, 2007, 2012; MRINJEK et al., 2012).

The Lower Palaeogene carbonate succession in the area is underlain by karstified Upper Cretaceous rocks (subaerial exposure commenced during the Campanian; MAMUŽIĆ, 1975). The Kozina beds, the oldest Palaeogene deposits, which originated locally within restricted lagoons are marked by a shift from freshand brackish-water environments to a fully marine regime in the area. During the Eocene the shallow-marine (neritic) carbonate succession rich in LBF, known as the Foraminiferal limestones, was deposited within carbonate ramp environments (DROBNE et al., 1991; BABIĆ \& ZUPANIČ, 2016 with references therein) over either the Kozina beds or directly onto karstified Cretaceous deposits. The ramp deposits pass upward into glauconite-bearing marly Transitional beds, overlain in some areas by a turbiditic succession of flysch and/or by a thick succession of Promina beds (MRINJEK et al., 2012).

The most important characteristic of the studied Palaeogene carbonate deposits are the abundance and diversity of the LBF. They are an endosymbiont-bearing (LEE, 1998; HALLOCK, 1999, and references therein), highly diversified and specialized group of organisms with specific environmental preferences regarding temperature, salinity, water energy, light intensity, and substrate type, numerous in the photic zone of oligotrophic tropical and subtropical seas (HOTTINGER, 1983, 1997; BOUDAGHER-FADEL, 2008). This makes them, apart from being major carbonate producers, excellent shallow-water environmental/ palaeoenvironmental indicators (HOTTINGER, 1983, 1997; HO- 

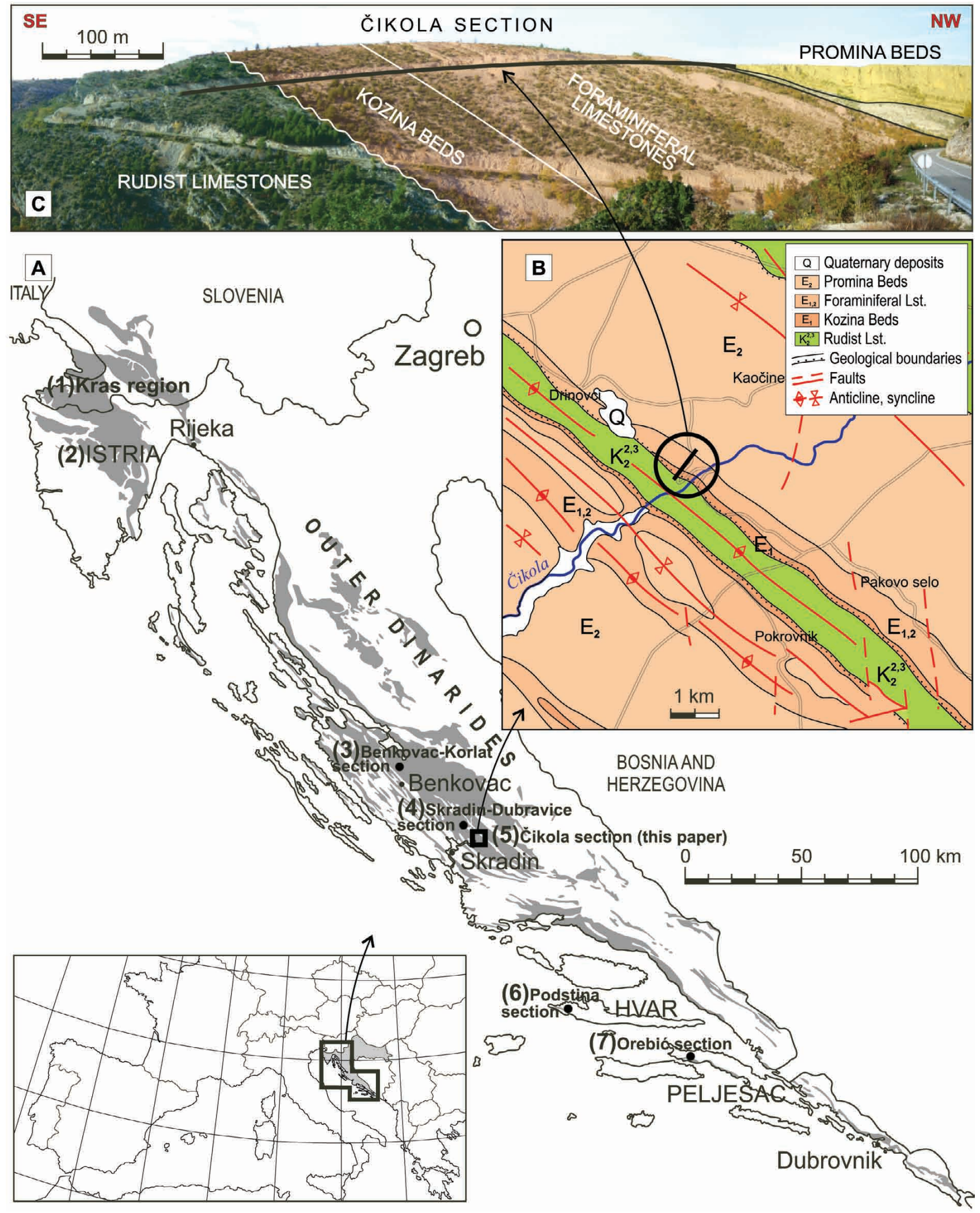

Figure 1. (A) Simplified location map of the Palaeogene deposits in the Dinarides (modified after ĆOSOVIĆ et al., 2008a; DROBNE et al., 2011) with the location of geological columns from Fig. 5, (B) geological map (modified after MAMUŽIĆ, 1971; IVANOVIĆ et al., 1973, 1977; ĆOSOVIĆ et al., 2008a; DROBNE et al., 2011; MRINJEK et al., 2012), and (C) panoramic view of the studied Čikola section. Late Cretaceous rudist limestones are unconformably overlain by the studied Kozina Beds and Lower Eocene Foraminiferal limestones, which are conformably overlain by the Promina beds (modified after MRINJEK et al., 2012).

HENEGGER, 2004, 2005), because their presence indicates specific water temperature, salinity, light conditions, energy and seabottom conditions. Based on the abundance of specific groups of LBF, the Foraminiferal limestones in the Outer Dinarides are often informally subdivided into separate members: miliolid-, alveolinid-, nummulitid-, and/or orthophragminid limestones. Deposits of each member originated under different palaeoenvironmental conditions, and their spatial and temporal distribution 
suggests an overall deepening of the sedimentary settings during the Early Eocene and early Middle Eocene.

Our results could shed additional light on the deposition of the Foraminiferal limestones, and provide more data about the evolution of the Northern Dalmatian Foreland Basin during the Eocene. New data will help in completing the picture of the evolution of the Eocene shallow-water (neritic) sedimentary system of the Outer Dinarides, including a discussion of palaeogeographical terminology.

\section{GEOLOGICAL SETTING AND STRATIGRAPHY}

The studied area represents part of the North Dalmatian Foreland Basin developed in front of the evolving Dinaric structures by tectonic deformation and marine transgression of an emerged and denuded Mesozoic Adriatic Carbonate Platform (AdCP). During the initial phase, a ramp was formed as a distal part of a foredeep in the Dinaric foreland basin system, and carbonate sedimentation existed on a flank of a broad forebulge until the Middle Eocene (BABIĆ \& ZUPANIČ, 2008, 2012).

Deposition during the Palaeogene was significantly controlled by tectonic deformation caused by the propagation of the Dinaric orogeny towards the SW. The Palaeogene shallow-marine (neritic) carbonates were deposited on a carbonate ramp (ĆOSOVIĆ et al., 2008a), named the Palaeogene Adriatic Carbonate Platform (PgAdCP) by DROBNE et al. (2009, 2011). The upward deepening of the carbonate ramp produced a $220 \mathrm{~m}$ thick succession (IVANOVIĆ et al., 1976) of carbonates in the studied region. The succession is composed of palustrine and marginal marine carbonates, often referred to as the Kozina beds overlain by neritic deposits known as the Foraminiferal limestones (for general overview see VLAHOVIĆ \& VELIĆ, 2009). Deposition of the overlying Transitional beds (ĆOSOVIĆ et al., 2008a) and turbiditic deposits (flysch) started when ramp carbonate production was unable to keep pace with subsidence. The subsequent shallowing of depositional environments is recorded in the small piggyback sub-basins within the Promina basin (KORBAR 2009; MRINJEK et al., 2012), where the succession of Promina beds (SCHUBERT, 1904, 1908; MAMUŽIĆ, 1971; IVANOVIĆ et al., 1973, 1977) of the Middle Eocene to Oligocene age were deposited in thickness of up to 2000 m (BABIĆ \& ZUPANIČ, 2012; MRINJEK et al., 2012).

\section{MATERIALS AND METHODS}

The studied section is located in the well-exposed road-cut along the local road passing across the Čikola river canyon (Fig. 1B, C). The geographic coordinates of the first and last sampled intervals are $43^{\circ} 50^{\prime} 8.9^{\prime \prime} \mathrm{N}, 16^{\circ} 2^{\prime} 49.3^{\prime \prime} \mathrm{E}$ and $43^{\circ} 50^{\prime} 20.4^{\prime \prime} \mathrm{N}, 16^{\circ} 2^{\prime} 58.2^{\prime \prime} \mathrm{E}$, respectively. The section encompasses a $310 \mathrm{~m}$ thick carbonate succession which was measured and sampled in detail to document both the sedimentological characteristics and fossil assemblages (Fig. 2).

Over 300 samples were collected for microfacies and micropalaeontological study and more than 270 thin sections representing various microfacies types were analysed. A total of 12 microfacies types have been defined based on LBF assemblages and sedimentary textures.

LBF assemblages were investigated in thin sections in order to determine the age of the deposits, applying the Shallow Benthic Zones (SBZs) of SERRA-KIEL et al. (1998). Taxonomic identification of foraminiferal tests was based on random thin sections and when sections allowed, identification to species level was done, using key literature for alveolinids (HOTTINGER,
1960; DROBNE, 1977), miliolids (DROBNE, 1974, 1985), and agglutinated conical foraminifera (HOTTINGER \& DROBNE, 1980; VECCHIO \& HOTTINGER, 2007).

Carbonate microfacies were distinguished according to DUNHAM's (1962) classification modified by EMBRY \& KLOVAN (1971). For the microfacies analysis the methods of WILSON (1975) and FLÜGEL (2010) were applied. In order to study environmental conditions, the visual examination and semi-quantitative analysis of lithology, grain types (biogenic or abiogenic), textures and fossil assemblages was performed. The modal distribution of components in thin sections was estimated by using a point-counting method (FLÜGEL, 2010). On each examined thin section, a two-dimensional grid of $1 \mathrm{~cm}^{2}$ was marked, and each grain within a grid was counted. From there, an estimated volume of a given grain type proportional to the counted numbers of a particular grain type was calculated. In descriptions of identified microfacies, to simplify the results, estimated volumes of particular grain types are presented semi-quantitatively by four subgroups: 'no grains', 'rare grains' (volume less than $15 \%$ ), 'common grains' (15 to $49 \%$ ), and 'abundant grains' (volume over $50 \%$ ). The microfacies types and foraminiferal assemblages enabled interpretation of the palaeoenvironmental conditions of the studied deposits similar to existing carbonate-ramp models (BUXTON \& PEDLEY, 1989; BURCHETTE \& WRIGHT, 1992; GEEL, 2000; POMAR, 2001; ROMERO et al., 2002; BASSI, 2005; BOSENCE, 2005; ZAMAGNI et al., 2008; TOMASSETTI et al., 2016). POMAR's (2001) subdivision of shallow-water carbonate environments from euphotic to oligophotic ones was also applied.

\section{RESULTS}

\subsection{Stratigraphy of the Čikola section}

The Palaeogene deposits in the studied Čikola section (Figs. 1, 2) may be divided into two stratigraphic units, $\mathrm{S} 1$ and $\mathrm{S} 2$, then further subdivided into five sub-units (S1a, S1b, S2a, S2b and S2c), based on their fossil content (mainly foraminifera) and sedimentary textures.

The S1 unit transgressively overlies massive light-coloured Upper Cretaceous rudist-bearing limestones. The non-depositional phase between the Upper Cretaceous and Palaeogene deposits is not easily recognizable in the field, since in the studied section it is not represented by any visible angular unconformity or infillings of continental deposits, and even karstification is not clearly visible everywhere. The detailed studies of thin sections reveal a reduction of fossils towards the youngest Cretaceous rocks, and the presence of Microcodium sp. aggregates in overlying beds, which are typical for the early stages of palaeosol development in many Peri-Tethyan sections (KOŠIR, 2004).

The oldest Palaeogene deposits, stratigraphic unit S1, are composed of an alternation of well-bedded wackestones to packstones and thin-bedded mudstones to wackestones. At the beginning of a succession, the thin-bedded limestones are intercalated with a few $\mathrm{cm}$ thick coal layers. The lower part of S1 unit, the Sla, is characterised by a specific fossil content (gastropods, charophyceae and ostracods), while in the upper, S1b unit, the decreasing abundance of ostracods and gastropods is related to the increasing abundance of small miliolids and discorbids.

The lower part of the overlying stratigraphic unit S2 consists of well-bedded foraminiferal wackestones to packstones with a rich LBF assemblage, whereas a massive appearance characterises deposits in the upper part of the unit. In the lowermost part - the 

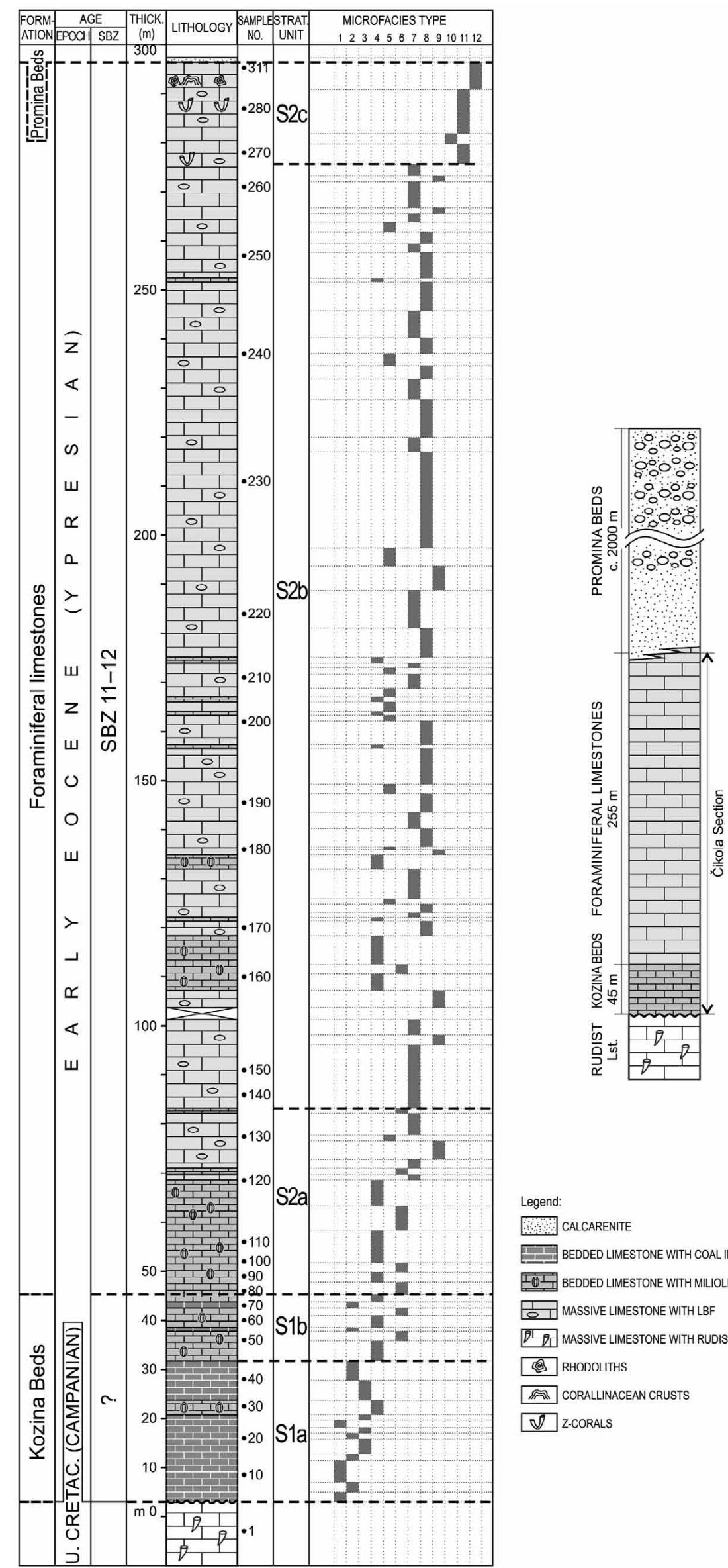

Legend:

CALCARENITE

BII BEDDED LIMESTONE WITH COAL INTERCALATIONS

FEII BEDDED LIMESTONE WITH MILIOLIDS

एव. MASSIVE LIMESTONE WITH LBF

D DA MASIIVE LIMESTONE WITH RUDISTS

RHODOLTHS

CORALINACEAN CRUSTS

(4) Z-CORALS

Figure 2. Studied stratigraphic column of the Čikola section showing the lithology, identified biozones (SBZ after SERRA-KIEL et al., 1998) and distribution of the microfacies types MFT 1 to MFT 12 (left), and position of the studied section within a generalized stratigraphic column of the Upper Cretaceous-Eocene succession in the Čikola Canyon, Northern Dalmatia (MRINJEK et al., 2012) (right). 
S2a unit-miliolids dominate, while the middle part (the S2b unit) has a diverse foraminiferal assemblage: miliolids, alveolinids, agglutinated conical foraminifera and Orbitolites sp. In the upper part of the unit, S2c, massive coarse-grained foraminiferal packstones occur with lenticular-shaped nummulites, fragments of zooaxanthellate corals (z-corals) and corallinacean red algae (including small rhodoliths) and rare orthophragminids. The top of the Čikola section is conformably overlain by massive mudstone beds with thin streaks, normal-graded interlaminae and lenses of silt or very fine-grained sand, interpreted as initial fine-grained subneritic deposits of the Promina beds (MRINJEK et al., 2012).

\subsection{Facies association and microfacies types}

Regarding the composition of foraminiferal assemblages and associated biota as well as sedimentary textures, the studied succession has been divided into twelve microfacies types, MFT 1 to MFT 12 (Fig. 2).

\subsubsection{MFT 1 - Non-fossiliferous mudstone to wackestone} Microfacies MFT 1 is composed of mudstones characterised by a lack of fossils, more or less intense recrystallization, often common scattered dolomite crystals, and locally visible Microcodium sp. clusters (Pl. 1, Fig. 1).

Interpretation: Carbonates of the MFT 1 microfacies were deposited in a shallow, inner ramp setting, where episodes of subaerial exposure (as indicated by Microcodium sp.) occurred. A lack of fossils characterised supratidal conditions within an inner ramp setting.

This microfacies overlays the Upper Cretaceous rudist-bearing limestones, and represents initial deposition over a regional unconformity (Cretaceous to Palaeogene stratigraphic hiatus).

\subsubsection{MFT 2 - Ostracod mudstone to wackestone}

MFT 2 consists of mudstones to wackestones containing common to abundant ostracod shells, common Decastronema barattoloi (DE CASTRO) cyanobacterial filaments and rare charophyceae (Pl. 1, Fig. 2). Samples with abundant ostracods often show lamination.

Interpretation: The low-diversity fossil assemblage composed of thin-shelled ostracods, charophyceans and cyanobacteria suggests episodic fresh-water influxes. The common presence of $D$. barattoloi, known as a pioneering organism in modifying the environments to become more suitable for other organisms (ĆOSOVIĆ et al., 2008b), supports such an interpretation. These described conditions are typical of low-energy, protected brackish lagoons.

This microfacies is typical for the basal part of the Čikola section, the Sla stratigraphic unit, representing the oldest Palaeogene deposits in the studied area (Fig. 2).

\subsubsection{MFT 3 - Dolomitized gastropod wackestone to packstone}

MFT 3 is represented by wackestones to packstones (Pl. 1, Fig. 3). Skeletal particles comprise abundant gastropods (Stromatopsis sp. and Cosinia sp.) and common charophyceae. The gastropod shells are often compressed, fragmented, and intraskeletal pores are infilled by fine-grained wackestone to packstone. Finegrained micritic matrix is often recrystallized, with common to abundant dolomite crystals scattered in the matrix or within interparticle cement.

Interpretation: The presence of charophyceae and gastropods indicate a freshwater influence, thus deposition probably took place in a brackish environment, whereas the micritic matrix suggests a low turbulence environment.
This microfacies occurs in the first $30 \mathrm{~m}$ of the Čikola section (Sla stratigraphical unit) and contains eight coal intercalations, each a few cms in thickness (Fig. 2).

\subsubsection{MFT 4 - Bioturbated miliolid mudstone to wackestone}

MFT 4 consists of mudstones to wackestones. The micritic matrix is locally recrystallized, and numerous voids are partly filled with micrite (due to intense bioturbation) and/or sparite. Bioclasts are rare to common, represented mostly by foraminifera such as abundant tests of discorbids, rare to common miliolids (Quinqueloculina sp., Spirolina sp., Pyrgo sp., Triloculina sp., and Idalina sp.), Cribrobulimina sp., and ostracods (P1. 1, Fig. 4). Small, $\mathrm{mm}$-sized voids filled with sparitic cement and engulfed in thick, micritic coatings, have spherical, subspherical and/or tubular shapes, are often clustered together, without any apparent pattern or orientation. Voids with similar form and dimensions could be interpreted as tubular fenestral voids (cf. FLÜGEL, 2010).

Interpretation: The sedimentological and palaeontological features imply deposition in a very shallow, low-energy, restricted marine environment, where small epiphytic foraminifera (small miliolids) and discorbids thrived. Occurrences of agglutinated conical foraminifera, related to protected, relatively nutrient-rich lagoonal environments (GEEL, 2000) support this environmental interpretation.

This microfacies, together with MFT 3, is a dominant microfacies in the lower $45 \mathrm{~m}$ of the Čikola section, but it occurs throughout the entire Čikola section, especially in stratigraphic units S2a and S2b to the $175 \mathrm{~m}$ of the Čikola section (Fig. 2).

\subsubsection{MFT 5 - Conical agglutinated foraminiferal packstone}

The main characteristic of MFT 5 is the abundance and diversity of conical agglutinated foraminifera (Pl. 1, Fig. 5; Pl. 1, Fig. 6): Cribrobulimina cf. carniolica, Pseudochrysalidina alva (SILVESTRI), Pfendericonus makarskae (VAN SOEST) and Coskinolina liburnica (STACHE). Other common benthic foraminifera are alveolinids and miliolids (including Periloculina dalmatina DROBNE; Pl. 1, Fig. 5).

Interpretation: According to HOTTINGER (1983, 1997), VECCHIO \& HOTTINGER (2007) and AFZAL et al. (2011) conical agglutinated foraminifera occupied soft muddy sea-bottom at depths just below the tidal level. Thus, this microfacies is interpreted as having been deposited in the protected, low-energy, shallowest parts of the innermost ramp.

This microfacies occurs in the stratigraphic unit $\mathrm{S} 2 \mathrm{~b}$ of the Cikola section. The first occurrence is at around $80 \mathrm{~m}$ and it is present almost until the end of the section (Fig. 2).

\subsubsection{MFT 6 - Miliolid wackestone to packstone}

The dominant lithology within MFT 6 are fine-grained wackestones to packstones (Pl. 1, Fig. 7), in which the micritic matrix is occasionally partially recrystallized. This microfacies is characterised by the abundance of both small and complex miliolids: Quinqueloculina sp., Spirolina sp., Pyrgo sp., Triloculina sp., and Idalina cf. sinjarica, as well as the rare to common presence of agglutinated conical foraminifera, Cribrobulimina cf. carniolica.

Interpretation: Sedimentological and palaeontological characteristics (the proportion of smaller and larger miliolids and agglutinated conical foraminifera - GEEL, 2000; ROMERO et al., 2002; VECCHIO \& HOTTINGER, 2007, AFZAL et al., 2011) of the MFT 6 microfacies suggests deposition in low- to moderate-energy environments of the inner ramp. 
This microfacies occurs for the first time at c. $35 \mathrm{~m}$ from the base of the Čikola section within the stratigraphic unit S1b, but prevails at the beginning of stratigraphic unit S2 (within subunit S2a), and continues up to the $110 \mathrm{~m}$ mark in the Čikola section (Fig. 2).

\subsubsection{MFT 7 - Alveolinid-miliolid packstone}

MFT 7 is represented by poorly-sorted packstones with a finegrained micritic (rarely coarse-grained) matrix (Pl. 1, Fig. 8; Pl. 2, Fig. 1). This microfacies is characterised by an abundance of porcelaneous foraminifera, mainly alveolinids and miliolids: $A l$ veolina decastroi SCOTTO DI CARLO, A. cremae CHECCHIA -RISPOLI, A. multicanalifera DROBNE, A. levantina HOTTINGER, Idalina cf. sinjarica, Spirolina sp., Quinqueloculina sp. and Pyrgo sp. Orbitolites complanatus LAMARCK tests are also common. The foraminiferal tests bear marks of bioerosion, and in some cases, the final whorls are missing. The occurrences of some 'deformed' orbitolitid tests (forms with additional perpendicular disks) are indicative of 'extreme' conditions (HOTTINGER, 1983) (Pl. 1, Fig. 8). Other bioclasts include rare tests of rotaliids, rare to abundant agglutinated conical foraminifera, Cribrobulimina sp., and Pseudochrysalidina alva (SILVESTRI), aborescent Haddonia sp., and fragments of echinoderms.

Interpretation: Sea-grass influenced associations rich in alveolinids and miliolids are interpreted as having originated in typical protected lagoonal settings (HOTTINGER, 1983, 1997; GEEL, 2000; BRANDANO et al., 2009a, b; TOMASSETTI et al., 2016), characterised by occasional short-lived episodes of increased temperature and/or salinity, as observed in tidal pools (causing 'deformed' orbitolitid tests - HOTTINGER, 1983).

This microfacies is dominant in the stratigraphic unit S2b of the Čikola section. The first occurrence is recorded around $70 \mathrm{~m}$ and it is present continuously almost until the end of the section (Fig. 2).

\subsubsection{MFT 8 - Peloidal-foraminiferal packstone}

The MFT 8 is represented by packstones with dominant peloids (Pl. 2, Fig. 2) of varying sizes and shapes, irregular to rounded, and foraminiferal tests. Fine-grained micritic matrix occasionally shows partial recrystallization. Where peloids are sparsely distributed, the micritic matrix and partially recrystallized matrix (sparitic matrix) occur, and where peloids are densely packed, it is hard to distinguish them from the surrounding micritic matrix. Dominant skeletal allochems are recrystallized rotaliid foraminifera. Porcelaneous foraminifera, which are mostly deformed and bioeroded, and echinoderm fragments are common. Skeletal remains are well-sorted and some of the agglutinated conical foraminifera are compacted.

Interpretation: Peloids are common in recent shallow subtidal to intertidal environments with moderate to restricted circulation (WILSON, 1975; TUCKER \& WRIGHT, 1990; FLÜGEL, 2010). The abundance of rotaliids and small miliolids indicates probable occurrences of sea-grass or algal covers, and thus euphotic conditions, within the shallow marine lagoon or inner ramp settings with possible open marine influence (LANGER, 1993; GEEL, 2000; MATEU-VICENS et al., 2010; POMAR et al., 2014).

This microfacies occurs in the stratigraphic unit S2b of the Čikola section, starting from 120 m (Fig. 2).

\subsubsection{MFT 9 - Foraminiferal grainstone}

MFT 9 consists of well-sorted bioclasts of miliolids, alveolinids, rotaliids, and micritized mollusc fragments (Pl. 2, Fig. 3). Occasionally alveolinid tests are oriented, fragmented and abraded.
Well-sorted grainstones are easily recognizable macroscopically because of the abundance of oriented, up to $3 \mathrm{~cm}$ long alveolinid tests.

Interpretation: MFT 9 represents a high-energy environment, under the influence of waves and currents. Alveolinids preferred algal or sea-grass substrates, although they could have lived on all kinds of substrates. They inhabited shallow-water, protected environments (including protected inner ramp settings) but, also, sand shoals near and below fair-weather wave base (GEEL, 2000). Abraded alveolinid tests and well-sorted grains indicate their probable deposition on inner ramp shoals. Generally, porcelaneous foraminifera (miliolids and alveolinids) are abundant in normal marine and, occasionally hypersaline lagoons (HOTTINGER, 1974; TORRICELLI et al., 2006).

This microfacies appears several times along the Čikola section within stratigraphic unit S2b (Fig. 2).

\subsubsection{MFT 10 - Nummulitid packstone}

The MFT 10 is composed of coarse-grained packstones with complete, fragmented and/or abraded (outer whorl missing) lenticular tests of nummulitids (Pl. 2, Fig. 4). The tests are randomly oriented, and the matrix is composed of fine bioclastic fragments. Nummulitid packstones are easily recognizable macroscopically because of the abundance of up to $15 \mathrm{~mm}$ long nummulitid tests.

Interpretation: The deposits identified as MFT 10 originated in a high-energy environment, where wave and current action was significant. Nummulitids are bottom dwellers, and can be found at depths less than $30 \mathrm{~m}$, but are dominant at mesophotic to oligophotic depths ( $\geq 30 \mathrm{~m}$; HOHENEGGER, 2005). Small- and medium-sized lenticular forms lived in various environments within the platform interior, and can form banks (AIGNER, 1983; GEEL, 2000). Specimens of Nummulites larger than $8 \mathrm{~mm}$ are frequent in nearshore shoals (TORRICELLI et al., 2006). The prevalence of tests larger than $8 \mathrm{~mm}$ suggests that rocks of this microfacies were deposited on shoals.

This microfacies appears in stratigraphic unit S2c of the Čikola section.

\subsubsection{MFT 11 - Coral-foraminiferal packstone}

MFT 11 is mainly composed of bioclastic-foraminiferal packstones while grainstones with corals (colonial and solitary, scattered in the skeletal matrix; Pl. 2, Figs. 5, 6) sporadically occur. Within the matrix, the diverse fossil association of corals, bryozoans, echinoderms, foraminifera, and coralline red algae is also an abundant one. Small lenticular nummulitids, rotaliids (Neorotalia ex gr. lithotamnica (UHLIG)), orthophragmids, and encrusting foraminifera (Acervulina linearis HANZAWA, Miniacina sp., Haddonia sp., Fabiania cassis (OPPENHEIM) and Gyroidinella magna LE CALVEZ) are common, whereas alveolinids, miliolids, and planktonic foraminifera are rare.

Interpretation: Coarse-grained matrix with numerous bioclasts (in particular, Neorotalia spp.) within packstones suggests a higher-energy environment. The co-occurrences of mixotrophs, such as z-corals and LBFs, suggests mesophotic conditions. The encrusting foraminifera are associated with corals (occupying cryptic and semi-cryptic microhabitats; BOSELLINI \& PAPAZZONI, 2003) and therefore follow the same environmental requirements as corals. It is known that in the mesophotic zone, corals lived and grew along with red algae (MORSILLI et al., 2012). In such settings, the high hydrodynamics provided the energy to rework bioclasts and produce skeletal packstones. 


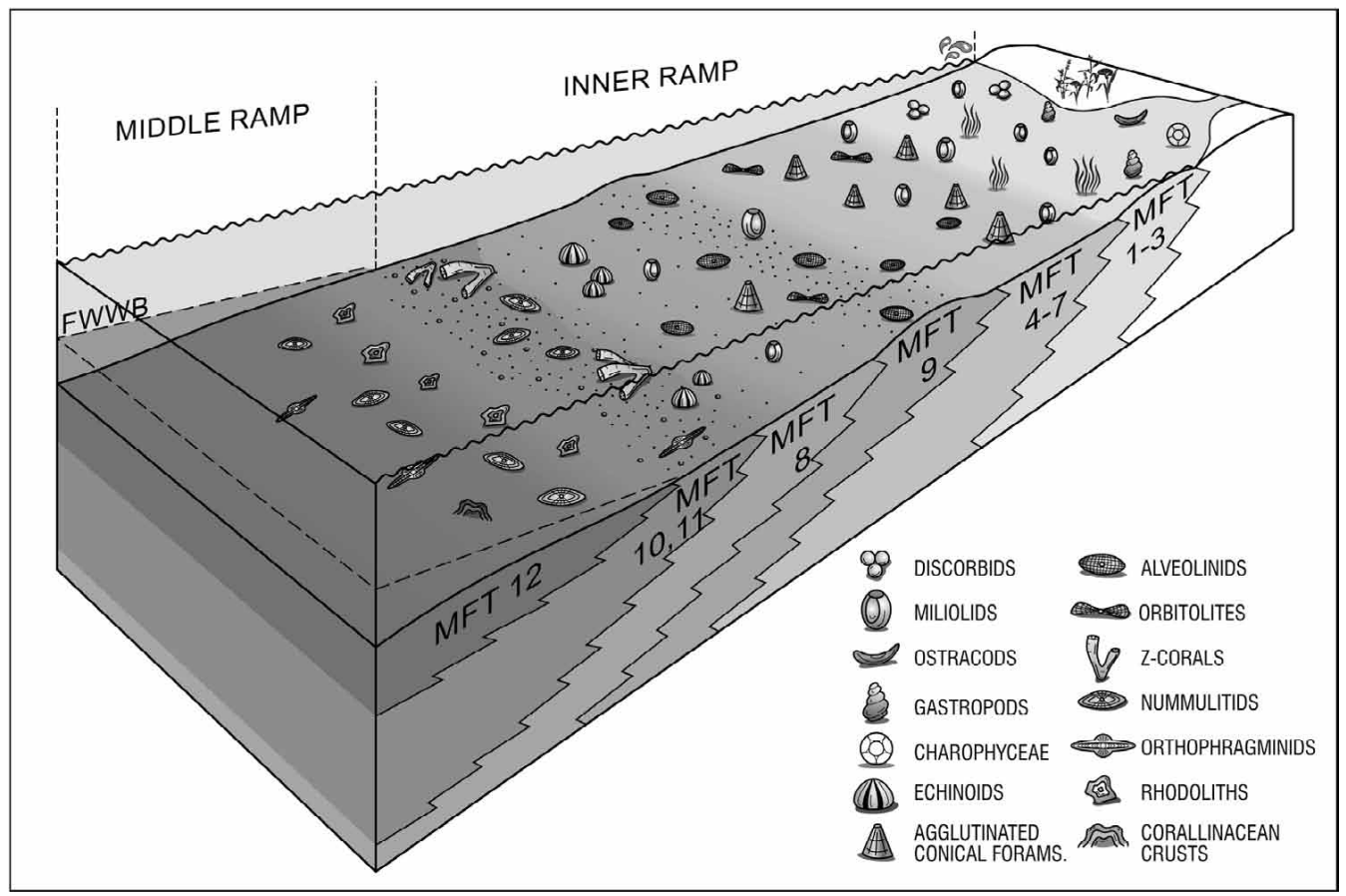

Figure 3. Schematic palaeoenvironmetal model of the Early Eocene Čikola carbonate ramp with interpreted facies belts: Brackish coastal environments (MFT 1-3); Protected lagoonal environments (MFT 4-7); Inner ramp environments (MFT 8, 11); Inner ramp shoals (MFT 9, 10), and Middle ramp environments (MFT 12).

This microfacies occurs in the last $30 \mathrm{~m}$ of the Čikola section, at the beginning of stratigraphic unit S2c (Fig. 2).

\subsubsection{MFT 12 - Rhodolith-nummulitid packstone}

MFT 12 is represented by poorly-sorted fine-grained micritic to coarse-grained packstones (Pl. 2, Figs. 7, 8). The main characteristics are small rhodoliths and fragments of coralline algae: Lithothamnion sp., Sporolithon sp., Mesophyllum sp., Lithoporella melobesioides (FOSLIE) and Polystrata alba (PFENDER). Fragments of corals or lithoclasts are overgrown by red algae and foraminifera (Miniacina sp., Solenomeris sp., and Acervulina linearis HANZAWA). Other skeletal allochems are ehinoderm fragments, broken LBFs (nummulitids, orthophragmids), and rotaliids.

Interpretation: Rhodoliths dominated by sporolithaceans and melobesioids occur below $60 \mathrm{~m}$ depth, and are characteristic of recent carbonate environments below the fair-weather wave base in tropical and subtropical seas (BASSI, 2005) in a wide variety of settings, including back-reef, reef-flat and channels, forereef and also in deeper water down to $250 \mathrm{~m}$ (BOSENCE, 1983). Rhodophyceae live at greater depths than other algae because they can better utilize the blue light that penetrates furthest into the water (LEE, 1998) and their occurrence marks the lower limit of the oligophotic zone. Coralline algae Lithotamnion sp. and Mesophyllum sp. are today found between 30 and $80 \mathrm{~m}$ depth on the Indo-Pacific shelves (ADEY, 1979) and similar facies were interpreted as being deposited in the upper photic zone (RASSER, 2000; NEBELSICK et al., 2013), as suggested by the occurrences of Nummulites (HOTTINGER, 1997). Small rhodoliths in packstones with fragmented bioclasts suggest some degree of bottom current reworking (BASSI, 2005).

Based on the skeletal composition and textures, deposits of this microfacies probably accumulated in a moderate-high energy areas within the mesophotic zone, probably in the proximal part of the middle ramp, well above the SWB, closer to FWWB.
This microfacies occurs only in the last $7 \mathrm{~m}$ of the Čikola section, at the end of the stratigraphic unit S2c (Fig. 2).

\subsection{Biostratigraphy}

The S1 unit of the Čikola section is characterised by occasional freshwater influences and alternating coal intercalations. The dominant organisms have no biostratigraphic value, so the determined fossil association does not allow age attribution.

In the S2b unit of the Čikola section, ranging from 80 to $276 \mathrm{~m}$ (Fig. 2), several stratigraphically important species of alveolinids (Alveolina decastroi, A. cremae, A. multicanalifera, A. levantina), conical agglutinated foraminifera (Pseudochrysalidina alva, Pfendericonus makarskae and Coskinolina liburnica), trematophore miliolids (Periloculina dalmatina) as well as Orbitolites complanatus have been identified within Conical agglutinated foraminiferal packstones (MFT 5) and Alveolinid-miliolid packstones (MFT 7). They indicate the SBZ 11-12 and therefore a Late Ypresian ('Cuisian') age for this carbonate unit.

\section{DISCUSSION}

During the Early Eocene in the studied area, a succession of carbonates around $300 \mathrm{~m}$ thick was deposited within shallow-water (neritic) settings, ranging from brackish to protected marine environments (represented by MFT 1 to MFT 7) to inner and middle carbonate ramp environments (represented by MFT 8 to MFT 12). A palaeoenvironmetal model for the studied succession is provided in Fig. 3. The Čikola succession is interpreted as having been deposited in subtropical, oligotrophic and euphotic to mixophotic environments based on microfacies characteristics.

A total of 12 microfacies types (MFT 1 to MFT 12) have been distinguished, demonstrating a diverse array of depositional and palaeoenvironmental conditions. They reflect a great diversity of shallow-marine biota, especially LBF as a highly diversified group with specific environmental preferences (HOTTINGER, 1983, 1997) within fluctuating environmental 
conditions. Restricted, lagoonal environments with fresh water influence (occurrences of charophyceae along with ostracods and gastropods) are recorded in microfacies units MFT 1 to MFT 3 (S1 unit in Fig. 2). Foraminiferal limestones (S2 unit in Fig. 2), composed of microfacies MFT 4 to MFT 12, with miliolids, LBF (including alveolinids and orbitolitids) and agglutinated conical foraminifera, were deposited in the inner ramp settings. Differentiation between two sub-settings based on the proportion of particular foraminiferal genera in assemblages was done. The microfacies MFT 4 and MFT 6 originated under low-energy conditions are characterised by the dominance of miliolids and sporadic occurrences of small, unidentified rotaliids. Diverse assemblages of alveolinids (fusiform to elliptical forms, representatives of A-generation), agglutinated conical foraminifera, larger miliolids, orbitolitids and z-corals characterised inner ramp settings. Where the influence of wave action was significant, shoals were formed, as indicated by the MFT 9 and MFT 10. The middle ramp settings were characterised by a high abundance of corallinacean red algae (MFT 12) while LBF are present in decreased proportions (Fig. 3). The dominance of fragments of LBF and macrofossils indicate the high-energy, well-lit part of the middle ramp. A melobesoid assemblage thrived in mid-latitudes within shallowwater warm-temperate settings (AGUIRRE et al., 2000). Fossil shallow-water corallinaceans have been reported from the Tethyan areas (BOSENCE, 1983; BASSI, 1998, 2005; BASSI \& NEBELSICK, 2010) and their co-occurrence with LBF indicates somewhat deeper settings. The succession ends with massive mudstone beds with thin streaks, normal-graded interlaminae and lenses of silt or very fine-grained sand, representing initial (prethrusting) fine-grained subneritic deposits belonging to the beginning of the Promina beds (MRINJEK et al., 2012), suggesting a probably tectonically induced ending of Foraminiferal limestone sedimentation. Deposition in the Čikola section was characterised by shallow-marine (neritic) environments showing an aggradational pattern, composed predominantly of inner-ramp deposits, above the FWWB, except for the last 10 metres. Foraminiferal limestones were deposited at the beginning of the foreland basin evolution and represent a bedrock of a wedge-top sub-basin filled up by Promina beds.

Lack of biostratigraphic markers in the S1 unit prevented precise age attribution of the oldest Palaeogene deposits, (the Kozina beds), in the Čikola section. In adjacent areas, the Palaeogene transgression started in the middle 'Cuisian' (SBZ 11; DROBNE et al., 1991). The beginning of sedimentation in the studied section is also assumed to be middle 'Cuisian', based on the fact that identified alveolinids and associated foraminifera from continuously overlying deposits, belong to the SBZ 11-12.

As mentioned, SBZs 11-12 correspond to the Late Ypresian (SERRA-KIEL et al., 1998) and during that period an almost $300 \mathrm{~m}$ thick succession of carbonates was deposited. Such a massive amount of carbonates testifies to a fine equilibrium having been established between the tectonically induced creation of accommodation space/subsidence and significant carbonate sediment production, especially as in the Cikola section there is no evidence of subsequent drowning in the form of Transitional beds and/or flysch deposits, typical for most other areas with Palaeogene deposits.

As evidenced, the main characteristic of these deposits is the abundant and diverse assemblage of LBF, major carbonate producers of the Early Palaeogene carbonate environments (HOTTINGER, 1997; PEARSON, 2012). Their occurrence in the area was controlled by the palaeolatitudinal position of the North Dal-

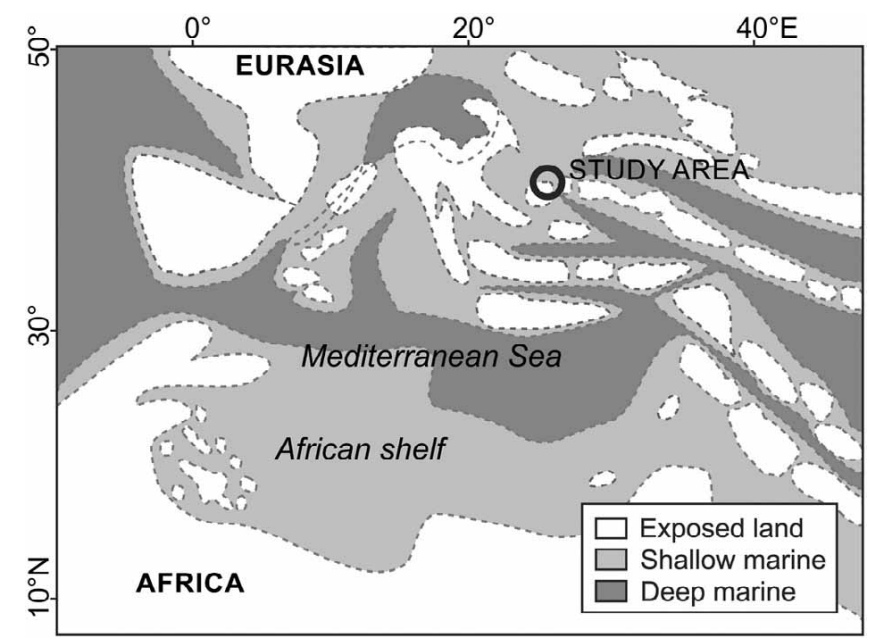

Figure 4. Simplified palaeogeographic reconstruction of the Mediterranean realm in the Early to Middle Eocene with marked position of the North Dalmatian Basin. The positions of the continents and ocean basins are adapted from MEULENKAMP \& SISSINGH $(2000,2003)$ as presented in HÖNTZSCH et al. (2013).

matian Foreland Basin during the Early Palaeogene, at approximately $38^{\circ} \mathrm{N}$ (MEULENKAMP \& SISSINGH, 2000, 2003) (Fig. 4) and by the early Palaeogene "warm" climate. The long-term global warming, beginning in the Late Palaeocene and culminating during the Early Eocene Climatic Optimum (EECO ZACHOS et al., 2001) with tropical sea-surface temperatures of 28 to $32^{\circ} \mathrm{C}$ (PEARSON et al., 2007), enabled abundant carbonate production even in the areas which should, according to their palaeolatitudes, be characterised by a more temperate climate. The sea-level fluctuations, along with variations in the configuration of the sedimentary basins and different subsidence rates, also contributed to such sedimentary scenarios (development of differentiated environments - from lagoons and shoals to innermiddle ramp settings).

Comparison with similar deposits from neighbouring regions (Figs. 1A and 5) reveals the following:

1) From NW to SE of the Dinaridic foreland the different array of settings (inner to outer ramp environments) within a carbonate ramp system have been recorded in the Kras region, Istria, Ravni kotari, Island of Hvar and Pelješac peninsula. An age discrepancy has been noticed concerning the beginning of the ramp conditions. In the NW part, in the Kras region (Slovenia, 1 on Fig. 5), the older part of the succession, the Liburnian Formation is of Maastrictian age (ZAMAGNI et al., 2008, 2012; JURKOVŠEK et al., 2016). Ramp settings commenced in Istria in the 'Ilerdian' (2 on Fig. 5; DROBNE, 1977; DROBNE et al., 2011; ĆOSOVIĆ et al., 2004, 2008a), in the Northern Dalmatia in the middle 'Cuisian' (3, 4 and 5 on Fig. 5; DROBNE et al., 1991; BABIĆ \& ZUPANIČ, 2016) in the Central Dalmatia in the earlymiddle 'Cuisian' (Pelješac and Hvar, 6 and 7 on Fig. 5; MARJANAC et al., 1998; SCHWEITZER et al., 2007).

2) The thicknesses of Palaeogene carbonate ramp system deposits vary from only $38 \mathrm{~m}$ (at Hvar, MARJANAC et al., 1998) to the maximum of $280 \mathrm{~m}$ (Benkovac area, DROBNE et al., 1991).

3) In some areas, including the studied one, the complete ramp system succession was not developed. Comparison with neighbouring regions reveals its complete development in Istria, whereas in Dalmatia (Ravni kotari, Hvar and Pelješac area) only some parts of the entire sequence were documented. 


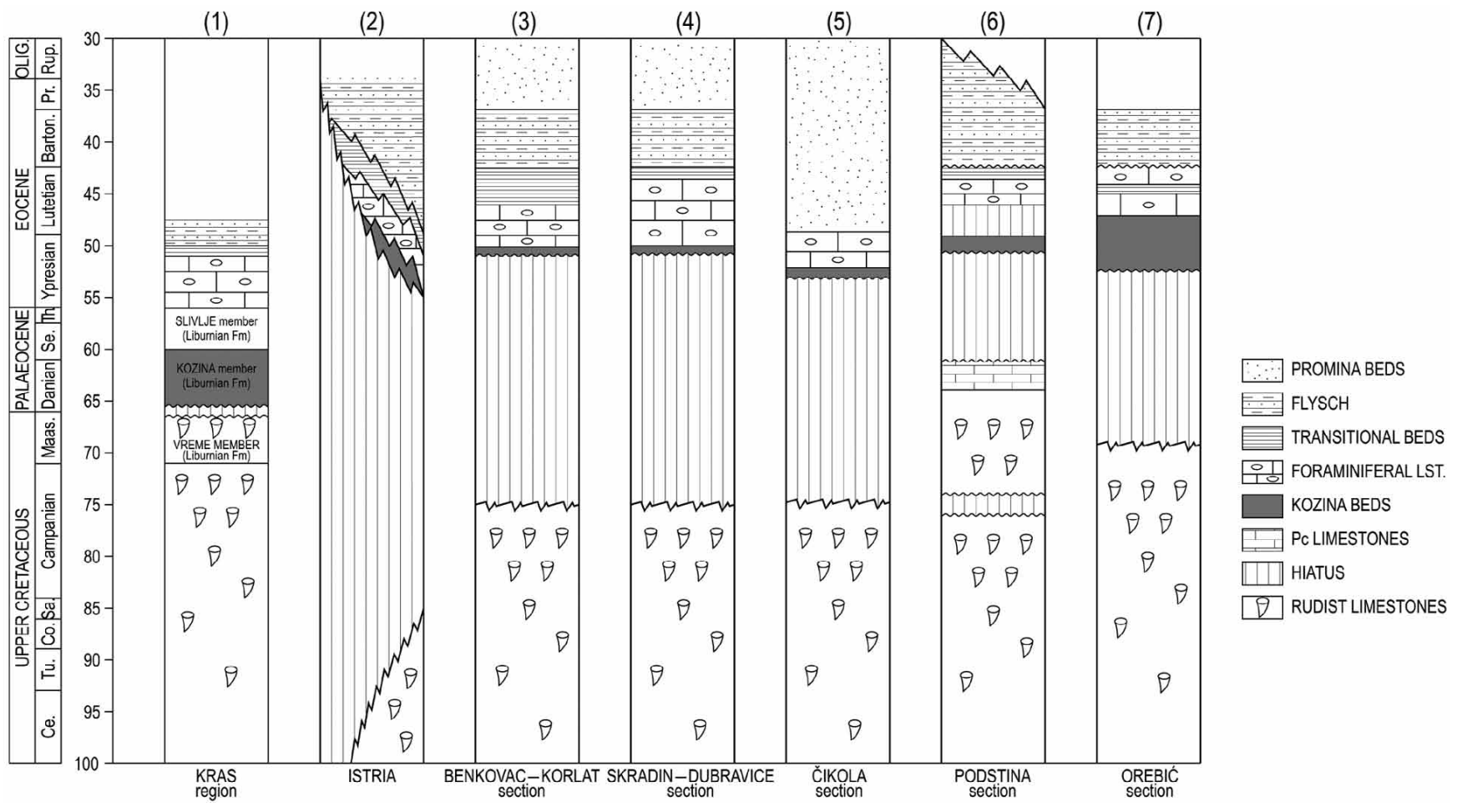

Figure 5. Schematic correlation of Cretaceous to Palaeogene carbonate and clastic successions in the area of the Dinarides (for location see Fig. 1), from NW to SE: (1) Kras region (modified after DROBNE \& PAVŠIĆ, 1991; ŽIVKOVIĆ \& BABIĆ, 2003; ZAMAGNI et al., 2008); (2) Istria (modified after BENIĆ, 1991; DROBNE \& PAVLOVEC, 1991; ĆOSOVIĆ et al., 2004); (3) Korlat-Benkovac section (modified after IVANOVIĆ et al., 1976; DROBNE et al., 1991); (4) Skradin-Dubravice section (modified after MAMUŽIĆ, 1975; DROBNE et al., 1991; MARJANAC \& ĆOSOVIĆ, 2000); (5) Čikola section (this paper); (6) Hvar, Podstina section (modified after PUŠKARIĆ, 1997; MARJANAC et al., 1998; PAVŠIČ \& PREMEC FUČEK, 2000: SCHWEITZER et al., 2007; KORBAR et al., 2015), and (7) Pelješac, Orebić section (modified after MARJANAC et al., 1998).

4) Deposition in the entire North Dalmatian area, from the middle 'Cuisian' onward, was characterised by more or less continuous shallow-marine environments, except for a narrow trench characterised by deeper-marine environments that developed in the Palaeocene and extended westward from Montenegro and eastern Herzegovina (CHOROWICZ, 1975; MARINČIĆ et al., 1976; JELASKA et al., 2003; ĆOSOVIĆ et al., 2006).

5) The discrepancy in age and physiography of depositional settings probably resulted from diachronous deformation of the progressively evolving orogen (KORBAR, 2009) during the Early to Middle Eocene. Intense tectonic activity might have prevented the full development of ramp settings. Therefore, the Palaeogene deposits in the Outer Dinarides may be considered as syn-orogenic deposits connected to the development and the evolution of foreland basin(s) and were deposited in basins controlled by deformation related to the Dinaric orogen (SCHMID et al., 2008; KORBAR, 2009).

Palaeogene deposits were accumulated on the deformed former AdCP, mostly above the regional unconformity (OTONIČAR, 2007; KORBAR, 2009; BRLEK et al., 2014). Gently folded AdCP deposits were during the Palaeogene gradually drowned and covered by a complex network of depositional environments for which the term Palaeogene Adriatic Carbonate Platform was proposed (DROBNE et al., 2009, 2011). However, during most of the Palaeogene, a completely different depositional system was formed, because (1) the former area of the Mesozoic AdCP was only partially covered by Palaeogene marine deposits, (2) instead of the previous vast, relatively flat shallow-marine Mesozoic AdCP, during the Palaeogene complex carbonate ramp depositional systems were formed, and (3) deposition was primarily con- trolled by compressional synsedimentary tectonics and although carbonate production (represented mostly by LBF) was an important factor (as shown in the Čikola section example), the prevailing force in modifying the accommodation space was tectonics, while on the AdCP, the dominant factor in sedimentation was carbonate production keeping balance with the subsidence (VLAHOVIĆ et al., 2005).

Therefore to avoid terminological confusion, a specific name for such a complex Palaeogene depositional system should be proposed, in order to clearly distinguish it from the underlying Adriatic Carbonate Platform.

\section{CONCLUSIONS}

In the Čikola Canyon, Northern Dalmatia, during the Early Eocene around $300 \mathrm{~m}$ of carbonates were deposited transgressively over the Upper Cretaceous (Campanian) rudist-bearing limestones, representing one of thicker successions of Palaeogene carbonates in the Dinarides. During the Early Eocene the sedimentation took place along a neritic carbonate ramp depositional system. In the studied section the carbonate succession comprises an older restricted, c. $45 \mathrm{~m}$ thick succession of very shallow-marine Kozina beds, and a late Ypresian (SBZ 11-12) Foraminiferal limestones succession deposited within inner to middle ramp environments. Foraminiferal limestones were dominated by larger benthic foraminifera (mostly conical agglutinated foraminifera, larger miliolids and alveolinids), and during the Upper Ypresian (cca. 2.6 Ma) approximately $250 \mathrm{~m}$ of shallow-marine carbonates were deposited in relatively stable environments, indicating a balance between tectonically induced subsidence and carbonate sedimentation. 
Based on lithology, grain types and fossil assemblages (mainly LBF) 12 microfacies types were identified, showing consolidation and development of a fully marine regime. Microfacies MFT 1 to MFT 3 are typical of deposits originating within restricted, unstable environments with the influence of fresh water. The inner ramp wackestones to packstones (microfacies MFT 4 to MFT 11), with abundant and diverse LBF assemblages were deposited under low- to high-energy conditions, i.e. in protected lagoons (MFT 5, 6, 7), inner high-energy parts of carbonate ramp (MFT 9, 10) and in distal inner ramp settings (MFT 11). The middle ramp environments were recorded by the MFT 12, where corallinaceans and LBF co-occurred.

From the latest Cretaceous to the Bartonian in the area of the Dinarides several carbonate ramp systems were developed. Each ramp system was characterised by its different evolution throughout its existence, including variable thickness, different ages of initiation and duration of marine conditions, and deposition in different sedimentary environments controlled primarily by synsedimentary tectonics related to the evolving Dinaric orogen.

\section{ACKNOWLEDGEMENT}

The authors are grateful to Katica DROBNE (Ljubljana), since this paper benefited greatly from her suggestions regarding alveolinids. Also, we would like to thank Robert KOŠĆAL for drawings, and Željko IŠTUK for help in thin section preparation. This study was sponsored by the support grant provided by the University of Zagreb, and partly supported by the Croatian Science Foundation under the project HRZZ IP-2014-09-9541. We would especially like to thank reviewers, Adrijan KOŠIR (Ljubljana) and Tvrtko KORBAR (Zagreb) for their suggestions that significantly improved this work.

\section{REFERENCES}

ADEY, W.H. (1979): Crustose coralline algae as microenvironmental indicators in the Tertiary.- In: GRAY, J. \& BOUCOT, A.J. (eds.): Historical Biogeography, Plate Tectonics and the Changing Environment. Oregon State Univ. Press, Corvallis, 459-464.

AFZAL, J., WILLIAMS, M., LENG, M.J., ALDRIDGE, R.J. \& STEPHENSON, M.H. (2011): Evolution of Paleocene to Early Eocene larger benthic foraminifer assemblages of the Indus Basin, Pakistan.- Lethaia, 44, 299-320. doi: 10.1111/j.1502-3931.2010.00247.x

AGUIRRE, J., RIDING, R. \& BRAGA, J.C. (2000): Diversity of coralline red algae: origination and extinction patterns from the Early Cretaceous to the Pleistocene.Paleobiology, 26, 651-667. doi: 10.1666/0094-8373(2000)026\%3C0651:DOCR $\mathrm{AO} \% 3 \mathrm{E} 2.0 . \mathrm{CO} ; 2$

AIGNER, T. (1983): Event-stratification in Nummulite accumulations and in shell beds from the Eocene of Egypt.- In: EINSELE, G. \& SEILACHER, A. (eds.): Cyclic and Event Stratification. Springer, Berlin, 248-262. doi: 10.1007/978-3-64275829-4 19

BABIĆ, Lj. \& ZUPANIČ, J. (1983): Paleogene clastic formations in northern Dalmatia.- In: BABIĆ, Lj. \& JELASKA, V. (eds.): Contributions to Sedimentology of some Carbonate and Clastic Units of the Coastal Dinarides, Excursion Guidebook. International Association of Sedimentologists 4th Regional Meeting, Split, 37-61.

BABIĆ, Lj. \& ZUPANIČ, J. (2007): Major events and stages in the sedimentary evolution of the Paleogene Promina basin (Dinarides, Croatia).- Natura Croatica, 16/4, 215-232.

BABIĆ, Lj. \& ZUPANIČ, J. (2008): Evolution of a river-fed foreland basin fill: the North Dalmatian flysch revisited (Eocene, Outer Dinarides).- Natura Croatica, 17, 357-374.

BABIĆ, Lj. \& ZUPANIČ, J. (2012): Laterally variable development of a basin-wide transgressive unit of the North Dalmatian foreland basin (Eocene, Dinarides, Croatia).- Geologia Croatica, 65, 1-27. doi: 10.4154/GC.2012.01

BABIĆ, Lj. \& ZUPANIČ, J. (2016): The youngest stage in the evolution of the Dinaric Carbonate Platform: the Upper Nummulitic Limestones in the North Dalmatian foreland, Middle Eocene, Croatia.- Natura Croatica, 25/1, 55-71.

BASSI, D. (1998): Coralline algal facies and their palaeoenvironments in the Late Eocene of northern Italy (Calcare di Nago, Trento).- Facies, 39, 179-202. doi: 10.1007/ BF02537016
BASSI, D. (2005): Larger foraminiferal and coralline algal facies in an Upper Eocene storm influenced, shallow water carbonate platform (Colli Berici, north-eastern Italy).- Palaeogeography, Palaeoclimatology, Palaeoecology, 226, 17-35. doi: 10.1016/j.palaeo.2005.05.002

BASSI, D. \& NEBELSICK, J.H. (2010): Components, facies and ramps: redefining Upper Oligocene shallow water carbonates using coralline red algae and larger foraminifera (Venetian area, northeast Italy).- Palaeogeography, Palaeoclimatology, Palaeoecology, 295, 258-280. doi: 10.1016/j.palaeo.2010.06.003

BENIĆ, J. (1991): The age of the Istria flysch deposits based on calcareous nannofossils.- In: DROBNE, K. \& PAVLOVEC, R. (eds.): Introduction to the Paleogene SW Slovenia and Istria. IGCP Project 286 "Early Paleogene Benthos", $2^{\text {nd }}$ Meeting Postojna, Paleontološki Inštitut I. Rakovca ZRC SAZU, Ljubljana, 25.

BOSELLINI, F.R. \& PAPAZZONI, C.A. (2003): Palaeoecological significance of coralencrusting foraminiferan associations: A case-study from the Upper Eocene of northern Italy.-Acta Palaeontologica Polonica, 48/2, 279-292.

BOSENCE, D.W.J. (1983): Coralline algal reef frameworks: Cenozoic carbonates.- Journal of the Geological Society, 140/3, 365-376. doi: 10.1144/gsjgs.140.3.0365

BOSENCE, D.W.J. (2005): A genetic classification of carbonate platforms based on their basinal and tectonic settings in the Cenozoic.- Sedimentary Geology, 175, 49-72. doi: 10.1016/j.sedgeo.2004.12.030

BOUDAGHER-FADEL, M.K. (2008): Evolution and geological significance of larger benthic foraminifera.- Development in Palaeontology and Stratigraphy, 21, Elsevier, $540 \mathrm{p}$.

BRANDANO, M., FREZZA, V., TOMASSETTI, L. \& CUFFARO, M. (2009a): Heterozoan carbonates in oligotrophic tropical waters: The Attard member of the lower coralline limestone formation (Upper Oligocene, Malta).- Palaeogeography, Palaeoclimatology, Palaeoecology, 274/1, 54-63. doi: 10.1016/j.palaeo.2008.12.018

BRANDANO, M., FREZZA, V., TOMASSETTI, L., PEDLEY, M. \& MATTEUCCI, R. (2009b): Facies analysis and palaeoenvironmental interpretation of the late Oligocene Attard Member (Lower Coralline Limestone Formation), Malta.- Sedimentology, 56, 1138-1158. doi: 10.1111/j.1365-3091.2008.01023.x

BRLEK, M., KORBAR, T., KOŠIR, A., GLUMAC, B., GRIZELJ, A. \& OTONIČAR, B. (2014): Discontinuity surfaces in Upper Cretaceous to Paleogene carbonates of central Dalmatia, Croatia: Glossifungites ichnofacies, biogenic calcretes, and stratigraphic implications.- Facies, 60/2, 467-487. doi: 10.1007/s10347-013-0378-9

BURCHETTE, T.P. \& WRIGHT, V.P. (1992): Carbonate ramp depositional systems.Sedimentary Geology, 79, 3-57. doi: 10.1016/0037-0738(92)90003-A

BUXTON, M.W.N. \& PEDLEY, H.M. (1989): A standardized model for Tethyan Tertiary carbonate ramps.- Journal of the Geological Society (London), 146, 746-748.

CHOROWICZ, J. (1975): Le devenir de la zone de Budva vers le Nord-Ouest de la Yougoslavie.- Bulletin de la Societe Geologique de France, 7/17, 699-709. doi: 10.2113/gssgfbull.S7-XVII.5.699

ĆOSOVIĆ, V., DROBNE, K. \& MORO, A. (2004): Paleoenvironmental model for Eocene foraminiferal limestones of the Adriatic carbonateplatform (Istrian Peninsula).- Facies, 50, 61-75.

ĆOSOVIĆ, V., PREMEC FUČEK, V., GUŠIĆ, I., JELASKA, V. \& MORO, A. (2006): The age of the Tilovica breccias in Central Dalmatia, Croatia.- Micropaleontology, 52, 281-286. doi: 10.2113/gsmicropal.52.3.281

ĆOSOVIĆ, V., MARJANAC, T., DROBNE, K. \& MORO, A. (2008a): Outer Dinarides: eastern Adriatic coast. Paleogene and Neogene.- In: McCANN, T. (ed.): The Geology of Central Europe, Volume 2: Mesozoic and Cenozoic. The Geological Society London, London, 1031-1139.

ĆOSOVIĆ, V., DROBNE, K., OGORELEC, B., MORO, A., KOIĆ, M., ŠOŠTARKO, I., TARLAO, A. \& TUNIS, G. (2008b): Decastronema barattoloi (De Castro), characteristic fossil of the Paleocene and the Eocene peritidal sediments from the Adriatic Carbonate Platform.- Geologia Croatica, 61, 321-332. doi: 10.4154/ GC.2008.24

DROBNE, K. (1974): Les grandes miliolidées des couches paléocènes de Yougoslavie du Nord-Ouest.- Razprave IV. razr. SAZU, 17, 129-184.

DROBNE, K. (1977): Alvéolines paléogènes de la Slovénie et de l'istrie.- Schweiz. Paläont. Abhandl., 99, 1-132.

DROBNE, K. (1985): Periloculina dalmatina a new trematophorid miliolid foraminifera from the Cuisian of Yugoslavia.- Razprave 4. razr. SAZU, 26, 159-176.

DROBNE, K. \& PAVLOVEC, R. (1991): Paleocene and Eocene beds in Slovenia and Istria.- In: DROBNE, K. \& PAVLOVEC, R. (eds.): Introduction to the Paleogene SW Slovenia and Istria. IGCP Project 286 "Early Paleogene Benthos", $2^{\text {nd }}$ Meeting Postojna, Paleontološki Inštitut I. Rakovca ZRC SAZU, Ljubljana, 7-18.

DROBNE, K. \& PAVŠIČ, J. (1991): Clastic carbonate deposits in SW Slovenia and Istria (Podsabotin beds - Paleocene; flysch - Paleocene, Eocene; Kožbana beds Paleocene; Međana beds - Eocene).- In: DROBNE, K. \& PAVLOVEC, R. (eds.): Introduction to the Paleogene SW Slovenia and Istria. IGCP Project 286 "Early Paleogene Benthos", $2^{\text {nd }}$ Meeting Postojna, Paleontološki Inštitut I. Rakovca ZRC SAZU, Ljubljana, 19-21.

DROBNE, K., VLAHOVIĆ, I., TRUTIN, M., PAVLOVEC, R., ĆOSOVIĆ, V., BABAC, D., CIMERMAN, F., LUČIĆ, D. \& PAVŠIČ, J. (1991): Excursion B - Ravni Kotari, Paleogene.- In: VLAHOVIĆ, I. \& VELIĆ, I. (eds): Some Aspects of the 
Shallow-water Sedimentation on the Adriatic Carbonate Platform (Permian to Eocene), 2nd International Symposium on the Adriatic Carbonate Platform, Excursion Guidebook. Institute of Geology, Zagreb, 53-70.

DROBNE, K., OGORELEC, B., PAVŠIČ, J. \& PAVLOVEC, R. (2009): Paleocene and Eocene in SW Slovenia.- In: PLENIČAR, M., OGORELEC, B. \& NOVAK, M. (eds.): Geology of Slovenia. Geološki zavod Slovenije, 311-372.

DROBNE, K., ĆOSOVIĆ, V., MORO, A. \& BUCKOVIĆ, D. (2011): The role of the Palaeogene Adriatic Carbonate Platform in the spatial distribution of Alveolinids.Turkish Journal of Earth Sciences, 20, 721-751.

DUNHAM, R.J. (1962): Classification of carbonate rocks according to depositional texture. In: HAM, W.E. (ed.): Classification of Carbonate Rocks. American Association of Petroleum Geologists Memoir, 1, 108-121.

EMBRY, A.F., III \& KLOVAN, J.S. (1971): A Late Devonian reef tract on northeastern Banks Island.- N.W.T. Bulletin of Canadian Petroleum Geology, 4, 730-781.

FLÜGEL, E. (2010): Microfacies of Carbonate Rocks.- Springer-Verlag, Berlin, 976 p. doi: 10.1007/978-3-642-03796-2

GEEL, T. (2000): Recognition of stratigraphic sequences in carbonate platform and slope deposits: empirical models based on microfacies analysis of Paleogene deposits in southeastern Spain.- Palaeogeography Palaeoclimatology Palaeoecology, 155, 211-238. doi: 10.1016/S0031-0182(99)00117-0

HALLOCK, P. (1999): Symbiont-bearing foraminifera.- In: SEN GUPTA, B.K. (ed.): Modern Foraminifera. Kluwer Academic Publishers, Dordrecht, 123-139. doi: 10.1007/0-306-48104-9 8

HOHENEGGER, J. (2004): Depth biocoenoclines and environmental considerations of Western Pacific larger foraminifera.- The Journal of Foraminifeal Research, 34, 9-33.

HOHENEGGER, J. (2005): Estimation of environmental paleogradient values based on presence/absence data: a case study using benthic foraminifera for paleodepth estimation.- Palaeogeography, Palaeoclimatology, Palaeoecology, 217, 115-130. doi: 10.1016/j.palaeo.2004.11.020

HÖNTZSCH, S., SCHEIBNER, C., BROCK, J.P. \& KUSS, J. (2013): Circum-Tethyan carbonate platform evolution during the Palaeogene: the Prebetic platform as a test for climatically controlled facies shifts.- Turkish Journal of Earth Sciences, 22, 891-918. doi:10.3906/yer-1207-8

HOTTINGER, L. (1960): Recherches sur les Alvéolines paléocènes et éocènes.- Schweizerische paläontologische Abhandlungen, 75-76, 1-236.

HOTTINGER, L. (1974): Alveolinids, Cretaceous-Tertiary Larger Foraminifera.- Esso Production research European laboratories, $84 \mathrm{p}$.

HOTTINGER, L. (1983): Processes determining the distribution of larger Foraminifera in space and time.- Utrecht Micropaleontol. Bull., 30, 239-253.

HOTTINGER, L. (1997): Shallow benthic foraminiferal assemblages as signals for depth of their deposition and their limitations.- Bulletin de la Société géologique de France, 168, 591-505.

HOTTINGER, L. \& DROBNE, K. (1980): Early Tertiary conical imperforate foraminifera.- Razprave IV. Razreda SAZU, 22, 186-276.

IVANOVIĆ, A., SAKAČ, K., MARKOVIĆ, S., SOKAČ, B., ŠUŠNJAR, M., NIKLER, L. \& ŠUŠNJARA, A. (1973): Osnovna geološka karta SFRJ 1:100000, list Obrovac [Basic Geological Map of SFRY 1:100000, Obrovac sheet - in Croatian].Geološki zavod, Zagreb, Savezni geološki zavod, Beograd.

IVANOVIĆ, A., SAKAČ, K., SOKAČ, B., VRSALOVIĆ-CAREVIĆ, I. \& ZUPANIČ, J. (1976): Osnovna geološka karta SFRJ 1:100000. Tumač za list Obrovac [Basic Geological Map of SFRY 1:100000, Geology of the Obrovac sheet - in Croatian, English Abstr.].--Geološki zavod, Zagreb, Savezni geološki zavod, Beograd, 61 p.

IVANOVIĆ, A., SIKIRICA, V., MARKOVIĆ, S. \& SAKAČ, K. (1977): Osnovna geološka karta SFRJ 1:100000, list Drniš [Basic Geological Map of SFRY 1:100000, Drniš sheet - in Croatian].- Geološki zavod, Zagreb, Savezni geološki zavod, Beograd.

JELASKA, V., BENČEK, Đ., CVETKO TEŠOVIĆ B., ĆOSOVIĆ, V., GUŠIĆ, I., IŠTUK, Ž. \& MATIČEC, D. (2003): Platform dynamics during the Late Cretaceous and Early Palaeogene - External Dinarides, Dalmatia.- In: VLAHOVIĆ, I. \& TIŠLJAR, J. (eds.): Evolution of Depositional Environments from the Palaeozoic to the Quaternary in the Karst Dinarides and the Panonnian basin, 22nd IAS Meeting of sedimentology - Opatija 2003, Field Trip Guidebook. Croatian Geological Survey, 101-107.

JURKOVŠEK, B., BIOLCHI, S., FURLANI, S.,KOLAR-JURKOVŠEK, T., ZINI, L., JEŽ, J., TUNIS, G., BAVEC, M. \& CUCCHI, F. (2016): Geology of the Classical Karst Region (SW Slovenia-NE Italy).- Journal of Maps, 12/S1, 352-362, doi: $10.1080 / 17445647.2016 .1215941$

KORBAR, T. (2009): Orogenic evolution of the External Dinarides in the NE Adriatic region: a model constrained by tectonostratigraphy of Upper Cretaceous to Paleogene carbonates.- Earth-Sci. Reviews, 96/4, 296-312. doi: 10.1016/j.earscirev.2009.07.004

KORBAR, T., MONTANARI, A., PREMEC FUĆEK, V., FUČEK, L., COCCIONI, R., McDONALD, I., ClAEYS, P., SCHULZ, T. \& KOEBERL, C. (2015): Potential Cretaceous-Paleogene boundary tsunami deposit in the intra-Tethyan Adriatic Car- bonate Platform section of Hvar (Croatia).- Geological Society of America Bulletin, 127/11-12, 1666-1680. doi: 10.1130/B31084.1

KOŠIR, A. (2004): Microcodium revisited: root calcification products of terrestrial plants on carbonate-rich substrates.- Journal of Sedimentary Research, 74/6, 845-857. doi: 10.1306/040404740845

LANGER, M.R. (1993): Epiphytic foraminifera.- Marine Micropaleontology, 20, 235-265. doi: 10.1016/0377-8398(93)90035-V

LEE, J.J. (1998): Living sands: Larger foraminifera and their endosymbiotic algae.Symbiosis, 25, 71-100.

MAMUŽIĆ, P. (1971): Osnovna geološka karta SFRJ 1:100000, list Šibenik [Basic Geological Map of SFRY 1:100000, Šibenik sheet - in Croatian].- Geološki zavod, Zagreb, Savezni geološki zavod, Beograd.

MAMUŽIĆ, P. (1975): Osnovna geološka karta SFRJ 1:100000. Tumač za list Šibenik K33-8 [Basic Geological Map of SFRY 1:100000, Geology of the Šibenik sheetin Croatian].- Geološki zavod, Zagreb, Savezni geološki zavod, Beograd, 37 p.

MARINČIĆ, S., KOROLIJA, B. \& MAJCEN, Ž. (1976): Osnovna geološka karta SFRJ 1:100000, list Omiš [Basic Geological Map of SFRY, Omiš sheet - in Croatian].Geološki zavod, Zagreb, Savezni geološki zavod, Beograd.

MARJANAC, T. \& ĆOSOVIĆ, V. (2000): Tertiary depositional history of Eastern Adriatic realm.- Vijesti Hrvatskoga geološkog društva, 37/2, 93-103.

MARJANAC, T., BABAC, D., BENIĆ, J., ĆOSOVIĆ, V., DROBNE, K., MARJANAC, LJ., PAVLOVEC, R. \& VELIMIROVIĆ, Z. (1998): Eocene carbonate sediments and sea-level changes on the SE part of Adriatic Carbonate Platform (Island of Hvar and Pelješac Peninsula, Croatia).- In: HOTTINGER, L. \& DROBNE, K. (eds.): Paleogene shallow benthos of the Tethys. Dela, Slov. Akad. Znan. Umetn. (SAZU), 34, 243-254.

MATEU-VICENS, G., BOX, A., DEUDERO, S. \& RODRÍGUEZ, B. (2010): Comparative analysis of epiphytic foraminifera in sediments colonized by seagrass Posidonia oceanica and invasive macroalgae Caulerpa spp.- The Journal of Foraminifeal Research, 40, 134-147. doi: 10.2113/gsjfr.40.2.134

MEULENKAMP, J.E. \& SISSINGH, W. (2000): Early to Middle Ypresian, late Lutetian, late Rupelian, early Burdigalian, early Langhian, late Tortonian, Piacenzian/Gelasian.- In: DERCOURT, J. \& GAETANI, M., ET AL. (eds.): Atlas Peri-Tethys, Palaeogeographical Maps. CCGM/CGMW, Paris, 17-23.

MEULENKAMP, J.E. \& SISSINGH, W. (2003): Tertiary palaeogeography and tectonostratigraphic evolution of the northern and southern Peri-Tethys platforms and the intermediate domains of the African-Eurasian convergent plate boundary zone.- Palaeogeography, Palaeoclimatology, Palaeoecology 196, 209- 228. doi: 10.1016/S0031-0182(03)00319-5

MORSILLI, M., BOSELLINI, F.R., POMAR, L., HALLOCK, P., AURELL, M. \& PAPAZZONI, C.A. (2012): Mesophotic coral buildups in a prodelta setting (Late Eocene, southern Pyrenees, Spain): a mixed carbonate-siliciclastic system.- Sedimentology, 59/3, 766-794. doi: 10.1111/j.1365-3091.2011.01275.x

MRINJEK, E., NEMEC, W., PECINGER, V., MIKŠA, G., VLAHOVIĆ, I., ĆOSOVIĆ, V., VELIĆ, I., BERGANT, S. \& MATIČEC, D. (2012): The Eocene-Oligocene Promina Beds of the Dinaric Foreland Basin in northern Dalmatia.- In: GAWLICK, H.J. \& LEIN, R. (eds.): 29th IAS Meeting of Sedimentology - Schladming 2012, Field Trip Guides. Geoaustria, Wien, 409-451.

NEBELSICK, J.H., BASSI, D. \& LEMPP, J. (2013): Tracking paleoenvironmental changes in coralline algal-dominated carbonates of the Lower Oligocene Calcareniti di Castelgomberto formation (Monti Berici, Italy).- Facies, 59/1, 133-148. doi: 10.1007/s10347-012-0349-6

OTONIČAR, B. (2007): Upper Cretaceous to Paleogene forebulge unconformity associated with foreland basin evolution (Kras, Matarsko Podolje and Istria; SW Slovenia and NW Croatia).- Acta Carsologica, 36/1, 101-120.

PAVŠIČ, J. \& PREMEC FUČEK, V. (2000): Calcareous nannoplankton and planktonic foraminiferal zones during the Middle and Upper Eocene of the "Transitional beds" of the Adriatic platform.- Annali di Museo Civico di Storia Naturali Ferrara, 3, 22-23.

PEARSON, P.N. (2012): Oxygen isotopes in foraminifera: overview and historical review.- In: IVANY, L.C. \& HUBER, B.T. (eds.): Reconstructing Earth's Deep-Time Climate - The State of the Art in 2012, Paleontological Society Short Course. The Paleontological Society Papers, 18, 1-38.

PEARSON, P.N., VAN DONGEN, B.E., NICHOLAS, C.J., PANCOST, R.D., SCHOUTEN, S., SINGANO, J.M. \& WADE, B.S. (2007): Stable warm tropical climate through the Eocene Epoch.- Geology, 35, 211-214. doi: 10.1130/ G23175A.1

POMAR, L. (2001): Types of carbonate platforms: a genetic approach.- Basin Research, 13, 313-334. doi: 10.1046/j.0950-091x.2001.00152.x

POMAR, L., MATEU-VICENS, G., MORSILLI, M. \& BRANDANO, M. (2014): Carbonate ramp evolution during the Late Oligocene (Chattian), Salento Penninsula, southern Italy.- Palaeogeography, Palaeoclimatology, Palaeoecology, 404, $109-132$.

PUŠKARIĆ, S. (1987): Calcareous nannoplankton from clastic sediments of the island of Hvar-- Radovi Jugoslavenske Akademije Znanosti i Umjetnosti, 22/431, 7-16. 
RASSER, M.W. (2000): Coralline red algal limestones of the Late Eocene Alpine Foreland Basin in Upper Austria: component analysis, facies and paleoecology.Facies, 42, 59-92. doi: 10.1007/BF02562567

ROMERO, J., CAUS, E. \& ROSELL, J. (2002): A model for the palaeoenvironmental distribution of larger foraminifera based on late Middle Eocene deposits on the margin of the South Pyrenean basin (NE Spain).- Palaeogeography, Palaeoclimatology, Palaeoecology, 179, 43-56. doi: 10.1016/S0031-0182(01)00406-0

SCHMID, S.M., BERNOULLI, D., FÜGENSCHUH, B., MATENCO, L., SCHEFER, S., SCHUSTER, R., TISCHLER, M. \& USTASZEWSKI, K. (2008): The AlpineCarpathian-Dinaridic orogenic system: correlation and evolution of tectonic units.Swiss Journal of Geosciences, 101, 139-183. doi: 10.1007/s00015-008-1247-3

SCHUBERT, R.J. (1904): Das Verbreitungsgebiet der Prominaschichten im Kartenblatte Novigrad Benkovac (Norddalmatien).- Jahrb. Geol. Reichsanst., 54, 461-510.

SCHUBERT, R.J. (1908): Geologische Spezialkarte der Österreichisch-ungarischen Monarchie, 1:75000. Novigrad und Benkovac.- Geologische Reichsanstalt, Wien.

SCHWEITZER, C.E., SHIRK, A.M., ĆOSOVIĆ, V., OKAN, Y., FELDMANN, R.M. \& HOŞGÖR, I. (2007): New species of Harpactocarcinus from the Tethyan Eocene and their paleoecological setting.- J. Paleont., 81, 1091-1100. doi: 10.1666/ pleo05-155.1

SERRA-KIEL, J., HOTTINGER, L., CAUS, E., DROBNE, K., FERRÀNDEZ, C., JAUHRI, A.K., LESS, G., PAVLOVEC, R., PIGNATTI, J., SAMSÓ, J.M., SCHAUB, H., SIREL, E., STROUGO, A., TAMBAREAU, Y., TOSQUELLA, J. \& ZAKREVSKAYA, E. (1998): Larger foraminiferal biostratigraphy of the Tethyan Paleocene and Eocene-- Bulletin de la Société géologique de France, 169, 281-299.

TOMASSETTI, L., BENEDETTI, A. \& BRANDANO, M. (2016): Middle Eocene seagrass facies from Apennine carbonate platforms (Italy).- Sedimentary Geology, 335, 136-149. doi: 10.1016/j.sedgeo.2016.02.002

TORRICELLI, S., KNEZAUREK, G. \& BIFFI, U. (2006): Sequence biostratigraphy and paleoenvironmental reconstruction in the Early Eocene Figols Group of the Tremp-Graus Basin (south-central Pyrenees, Spain).- Palaeogeography, Palaeoclimatology, Palaeoecology, 232, 1-35.
TUCKER, M.E. \& WRIGHT, V.P. (1990): Carbonate Sedimentology.- Blackwell, Oxford, 496 p. doi: 10.1002/9781444314175

VECCHIO, E. \& HOTTINGER, L. (2007): Agglutinated conical foraminifera from the Lower-Middle Eocene of the Trentinara Formation (southern Italy).- Facies, 53, 509-533. doi: 10.1007/s10347-007-0112-6.

VLAHOVIĆ, I., TIŠLJAR, J., VELIĆ, I. \& MATIČEC, D. (2005): Evolution of the Adriatic Carbonate Platform: paleogeography, main events and depositional dynamics.- Palaeogeography, Palaeoclimatology, Palaeoecology, 220, 333-360. doi: 10.1016/j.palaeo.2005.01.011

VLAHOVIĆ, I. \& VELIĆ, I. (2009): Liburnijske naslage, foraminiferski vapnenci i prijelazne naslage (?gornji paleocen, donji i srednji eocen-?Pc, $\mathrm{E}_{1,2}$ ) [Liburnian deposits, Foraminiferal limestones and Transitional Beds (? Upper Paleocene, Lower and Middle Eocene -?Pc, $E_{1,2}$ - in Croatian].- In: VELIĆ, I. \& VLAHOVIĆ, I (eds.): Tumač Geološke karte Republike Hrvatske 1:300000 [Explanatory Notes of Basic Geological Map of Croatia 1:300000 - in Croatian]. Hrvatski geološki institut, Zagreb, 76-77.

WILSON, J.L. (1975): Carbonate Facies in Geologic History.- Springer-Verlag, New York, 471 p. doi: 10.1007/978-1-4612-6383-8

ZACHOS, J., PAGANI, M., SLOAN, L., THOMAS, E. \& BILLUPS, K. (2001): Trends, rhythms, and aberrations in global climate 65 Ma to present.- Science, 292, 686-693. doi: 10.1126/science. 1059412

ZAMAGNI, J., MUTTI, M., BALLATO, P. \& KOŠIR, A. (2012): The Paleocene-Eocene thermal maximum (PETM) in shallow-marine successions of the Adriatic carbonate platform (SW Slovenia).- Geological Society of America Bulletin, 124/7-8, 1071-1086.

ZAMAGNI, J., MUTTI, M. \& KOŠIR, A. (2008): Evolution of shallow benthic communities during the Late Paleocene-earliest Eocene transition in the Northern Tethys (SW Slovenia).- Facies, 54, 25-43. doi: 10.1007/s10347-007-0123-3

ŽIVKOVIĆ, S. \& BABIĆ, Lj. (2003): Paleoceanographic implications of smaller benthic and planktonic foraminifera from the Eocene Pazin Basin (Coastal Dinarides, Croatia).- Facies, 49, 49-60

\section{Plate 1}

Photomicrographs of the Lower Eocene limestones microfacies types of the studied Čikola section:

1) Microcodium sp. in Non-fossiliferous mudstone to wackestone (MFT 1), sample Č1.8;

2) Charophyceae in Ostracod mudstone to wackestone (MFT 2), sample Č 1.21;

3) Compressed gastropod shells (on the left) and fragments of gastropod shells and charophyceae (on the right) in Dolomitized gastropod wackestone to packstone (MFT 3), sample Č1.26;

4) unidentified small miliolid and discorbids in Bioturbated miliolid mudstone to wackestone (MFT 4), sample Č1.65;

5) Conical agglutinated foraminiferal packstone (MFT showing Periloculina dalmatina DROBNE, unidentified small miliolids and agglutinated conical foraminifera, sample Č1.174;

6) Coskinolina liburnica (STACHE) and Pseudochrysalidina sp. in Conical agglutinated foraminiferal packstone (MFT 5), sample Č1.239;

7) Miliolid wackestone to packstone characterised by the abundance of small miliolids, Spirolina sp. and simple conical agglutinated foraminifera, Cribrobulimina sp. (center), sample Č1.63;

8) Alveolinid-miliolid packstone (MFT 7) showing a fragment of orbitolitid test with the additional perpendicular disk in association with small miliolids and Cribrobulimina sp., sample Č1.246. 

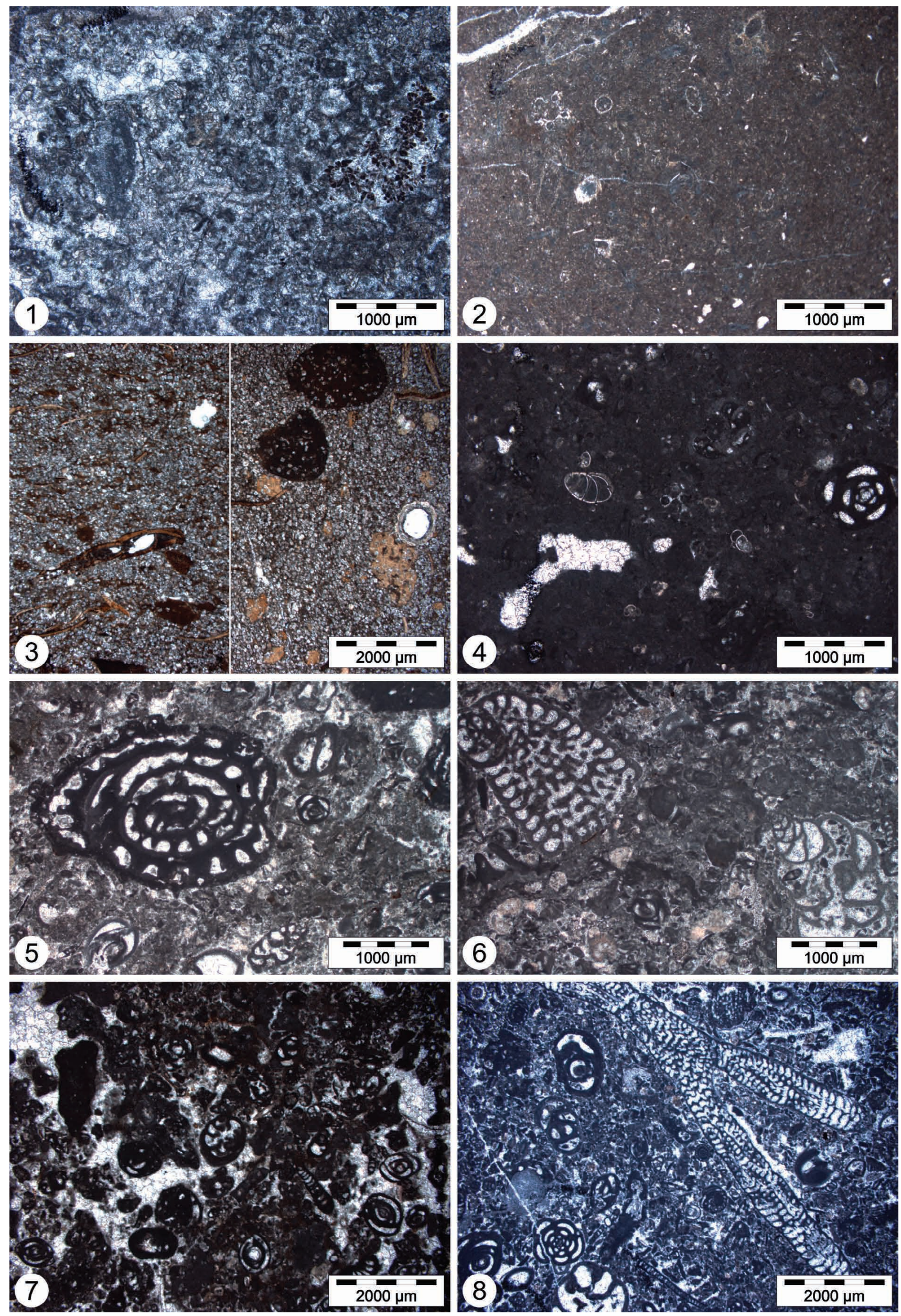
Plate 2

Photomicrographs of the Lower Eocene limestones microfacies types in the studied Čikola section:

1) Alveolina cremae CHECCHIA-RISPOLI in Alveolinid-miliolid packstone (MFT 7), sample Č1.232

2) Peloidal-foraminiferal packstone (MFT 8) defined by peloids, unidentified rotaliid foraminifera and fragmented alveolinids, sample Č1.186;

3) Foraminiferal grainstone (MFT 9) showing association of miliolids, alveolinids and micritized echinoid radiolas, sample Č1.158;

4) Unidentified Nummulites in Nummulitid packstone (MFT 10), sample Č1.275;

5) Coral-foraminiferal packstone (MFT 11) showing a detail of a coral, sample Č1.298,

6) Fragments of echinoids, coralline algae, alveolinids and unidentified small rotaliids in Coral-foraminiferal packstone (MFT 11), sample Č1.296;

7) Detail of encrusting foraminifera Solenomeris sp. (on the left) in Rhodolith-foraminiferal packstone (MFT 12) with fragments of echinoids, corals, orthophragminids and planktonic foraminifera (right from the centre), sample Č1.302;

8) Rhodolith-foraminiferal packstone showing fragmented foraminifera and Lithothamnion sp. crusts, sample Č1.301. 

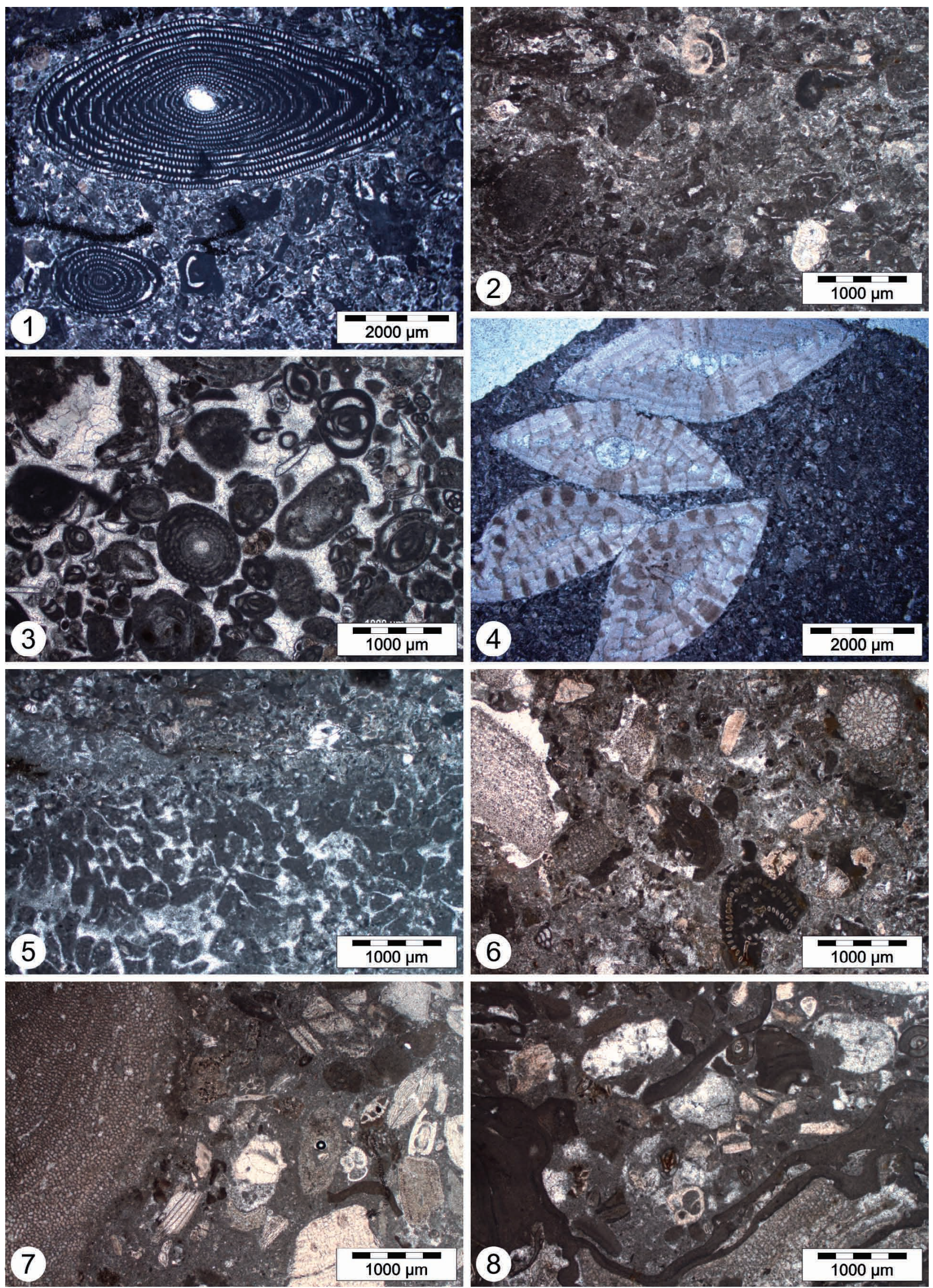
